\title{
POLEMIK KEBHINNEKAAN INDONESIA PADA INFORMASI INSTAGRAM @INFIA_FACT TERKAIT PATUNG KWAN SING TEE KOEN TUBAN
}

\author{
Rustono Farady Marta \\ Ilmu Komunikasi, Universitas Bunda Mulia \\ Alamat surel: rmarta@bundamulia.ac.id, rustonofarady@gmail.com
}

\begin{abstract}
The Indonesian nation is known for its diversity, but immediately a polemic caused by the rapid dissemination of information and social construction Instagram media to reality. The information provided tends to be biased as a result of the netizen's debate that could impact people in seconds. One of Instagram @Infia_fact account uploaded an information about the statue of Dewa Kwan Sing Tee Koen in Tuban City of East Java. This account is flooded with over 4000 netizen comments both positive and negative precursors, while this account uploads news without any tendency, purely. Social construction theory (Berger \& Luckman, 2011) works to describe this phenomenon through a comprehensive review, overcome the process of externalization, objectivization, and internalization.
\end{abstract}

Keywords: Diversity, @Infia_fact, Social Construction, God Statue

\begin{abstract}
Abstrak
Bangsa Indonesia dikenal oleh karena kebhinnekaannya, namun seketika terjadi suatu polemik yang disebabkan oleh cepatnya penyebaran informasi serta konstruksi sosial media Instagram terhadap realitas. Informasi yang diberikan cenderung menjadi bias akibat perdebatan para netizen yang dapat berdampak pada masyarakat hanya dengan hitungan detik. Salah satu akun Instagram @Infia_fact mengunggah sebuah informasi tentang patung Dewa Kwan Sing Tee Koen di Kota Tuban Jawa Timur. Akun ini dibanjiri dengan lebih dari 4000 komentar netizen baik yang berpresenden negatif maupun positif, sementara akun tersebut mengunggah berita tanpa adanya tendensi apapun, murni berupa fakta. Teori konstruksi sosial (Berger \& Luckman, 2011) bekerja untuk menjabarkan fenomena ini melalui penelaahan yang komprehensif, meliputi proses eksternalisasi, objektivasi, dan internalisasi.
\end{abstract}

Kata Kunci: Kebhinnekaan, @Infia_fact, Konstruksi Sosial, Patung Dewa

\section{PENDAHULUAN}

Kemajemukan masyarakat Indonesia merupakan sebuah ciri khas yang tidak dapat dipungkiri, hal ini terwujud melalui ragam suku, bahasa, tradisi, yang tersaji sebagai kearifan budaya daerah dari pangkal paling barat Negara Indonesia di Sabang hingga ke paling ujung Timur yang ditandai Merauke. Kemajemukan Bangsa Indonesia ini dikenal dengan istilah Bhinneka Tunggal Ika, yang dapat diartikan sebagai beragam tapi satu dalam kebangsaan, satu dalam kenegaraan, satu dalam nasionalisme yang sama, dan satu dalam kebahasaan. Bila ditelusuri berdasarkan asal-usul faal penciri fisik manusia Indonesia menunjukkan warna kulit, bentuk rambut, kornea mata, tinggi tubuh, tulang hidung dan pipinya adalah perpaduan seluruh ras di dunia. (Hidayah, 2015:ix)

Kondisi yang majemuk ini mendukung penetapan prinsip Bhinneka Tunggal Ika untuk dikukuhkan sebagai salah satu dari empat pilar kebangsaan, selain Pancasila, UUD 1945, dan Negara Kesatuan Republik Indonesia (NKRI). Kebhinekaan ini tidak hanya pada ranah budaya, terlebih juga terwujud melalui ragam agama yang dianut oleh masyarakat Indonesia. Terdapat enam agama yang secara resmi diakui oleh pemerintah Republik Indonesia berdasarkan UU Nomor 5 Tahun 1969, yaitu: Islam, Kristen, Katholik, Hindu, Budha, dan Khonghucu. Penetapan ini memberi ruang pada peluang terjalinnya kondisi kehidupan sosial masyarakat yang harmonis, seperti tercermin secara eksplisit dari bangunan 
ragam agama pada sebuah kawasan terintergrasi di Taman Mini Indonesia Indah (TMII) yang terletak di Jakarta Timur. Pada TMII tampak berdirinya enam bangunan berlatar belakang agama berbeda, yaitu Mesjid Pangeran Diponegoro, Gereja Kristen Protestan Haleluya, Gereja Katolik Stasi Santa Catharina, Wihara Budha Arya Dwipa Arama, Pura Hindu Penataran Agung Kertabhumi, serta Klenteng Khonghucu Kong Miao. Selain itu, TMII juga mengakomodir para penghayat aliran kepercayaan dan kebatinan dengan mendirikan Sasana Adirasa Pangeran Samber Nyawa.

Pemandangan tidak jauh berbeda juga terjadi di Denpasar Bali, yaitu kawasan yang disebut Puja Mandala berisi lima bangunan tempat ibadah. Pusat peribadatan ini terdiri dari Mesjid Ibnu Batutah, Gereja Kristen Protestan Bali (GKPB) Jemaat Bukit Dua, Gereja Katholik Paroki Maria Bunda Segala Bangsa, Vihara Buddha Guna, serta Pura Jagatnatha. Penetapan lima agama merupakan implikasi pola diskriminasi yang telah diterapkan pemerintah Orde Baru melalui Instruksi Presiden Soeharto No.1470 Tahun 1978. Inpres ini diperkuat kembali Surat Edaran (SE) Menteri Dalam Negeri
No.477/740554/BA.01.2/4683/95 tanggal 18 November 1978. Berbagai diskriminasi terhadap agama Khonghucu perlahan sirna sejak Keputusan Presiden K.H. Abdurrahman Wahid Nomor 6 Tahun 2000. Presiden keempat Republik Indonesia yang akrab dipanggil Gus Dur ini telah berjasa mencabut Inpres No.14 Tahun 1967 tentang agama, kepercayaan, dan adat istiadat Cina.

Seiring derasnya gelombang Reformasi ketika itu, Majelis Tinggi Agama Khonghucu Indonesia (MATAKIN) mengadakan Musyawarah Nasional XIII bertempat di Asrama Haji Pondok Gede, Jakarta pada tanggal 22-23 Agustus 1998. Pada Munas tersebut berhasil menetapkan Panca Dharma Badan Pengurus MATAKIN 1998-2002 yang menggagas suatu perayaan nasional pertama kalinya selama sejarah untuk memperingati Tahun Baru Imlek Nasional 2551 di Jakarta pada tanggal 17 Februari 2001. Peluang kebebasan sejak saat itu pula memberi tempat bagi agama Khonghucu melalui Peraturan Pemerintah Nomor 55 Tahun 2007 tentang Pendidikan Agama dan Pendidikan Keagamaan, salah satu pasalnya mengamanatkan mata pelajaran agama Khonghucu diterapkan pada kurikulum formal sejak bangku sekolah.

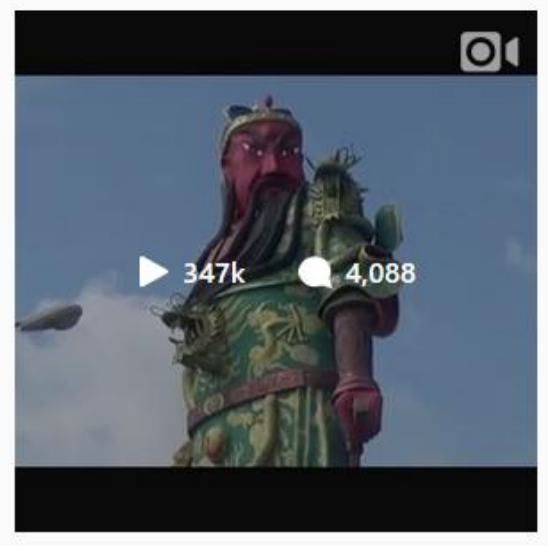

Sumber: Instagram di akun @infia_fact

Gambar 1. Viewers dan Comments untuk Video Patung Dewa di akun @infia_fact

Pada kenyataannya di bumi Indonesia, terjadi konflik antar ragam pemeluk agama. Hal ini dapat ditemui pada sebuah informasi yang diunggah akun Instagram "Infia_Fact" melalui video beserta sejumlah keterangan tambahan, sehingga menyebabkan para netizen ramai melakukan perbincangan hingga perdebatan sengit di akun tersebut. Adapun informasi teknis terkait patung dewa yang berada di kawasan tempat ibadah Tri Dharma Kwan Sing Bio, Tuban, Jawa Timur. Tegap berdiri setinggi 
30 meter itu diresmikan pada 17 Juli 2017 oleh Ketua MPR RI Bapak Zulkifli Hasan dan diklaim sebagai patung panglima perang paling tinggi di Asia Tenggara. Patung ini juga merupakan bentuk representasi dari Dewa Perang yang dipuja oleh umat Konghucu jauh sebelum Republik Rakyat Tiongkok berdiri.

Informasi ini menjadi perdebatan berunsur SARA (Suku Agama Ras Antar golongan) dikarenakan munculnya penyebar isu atau rumor yang menyimpang hingga beberapa opini miring di media sosial yang membanding-bandingkan tinggi patung ini dengan patung Jendral Sudirman di Jakarta yang jauh lebih kecil. Bahkan banyak sekali tunduhan-tuduhan bahwa patung tersebut didirikan di alun-alun kota Tuban, maka netizen beranggapan bahwa patung tersebut merupakan keputusan yang salah karena masih banyak pahlawan-pahlawan nasional yang lebih berjasa dalam masa-masa perjuangan merebut kemerdekaan Indonesia dulu yang lebih pantas untuk diabadikan dan diapresiasi menjadi sebuah patung.

Begitu kuatnya pengaruh dari media sosial, khususnya media instagram yang sedang digandrungi dalam memberikan efek kepada para penggunanya. Banyak sekali informasi-informasi yang masih belum bisa dikatakan jelas sumbernya tetapi tersebar luas dan menjadi viral di masyarakat, sehingga memicu pro kontra dari para netizen dalam menyikapi berita tersebut. Dari fenomena tersebut timbulah sebuah pertanyaan, proses konstruksi akun instagram "infia fact" terhadap sebuah informasi mengenai berita Patung Panglima Perang di Tuban dalam media sosial Instagram "infia_fact".

\section{TINJAUAN TEORITIS}

Teori yang digunakan untuk menjabarkan penelitian ini adalah Teori Konstruksi Sosial, dimana istilah konstruksi atas realitas sosial diperkenalkan oleh Peter L. Berger dan Thomas Luckman (2011). Konstruksi ini berusaha menggambarkan proses sosial melalui tindakan dan interaksinya, dimana individu menciptakan secara terus menurut suatu realitas yang dimiliki dan dialami bersama secara subyektif.

Dalam aliran filsafat, gagasan konstruktivisme telah muncul sejak Socrates menemukan jiwa dalam tubuh manusia, sejak Plato menemukan akal budi dan ide. Gagasan tersebut semakin lebih konkret lagi setelah Aristoteles mengenalkan istilah: informasi, relasi, individu, substansi, materi, esensi dan sebagainya. Ia mengatakan bahwa manusia adalah makhluk sosial, setiap penyataan harus dibuktikan kebenarannya, bahwa kunci pengetahuan adalah logika dan dasar pengetahuan adalah fakta (Bertens dalam Bungin, 2008:13).

Realitas sosial yang sedang dihadapi merupakan kontroversi antara pro dan kontra mengenai patung tersebut. Realitas mengenai kontroversi inlah yang akan diuraikan menggunakan Teori Konstruksi Sosial.

Berger dan Luckman (Bungin, 2008:14) mulai menjelaskan realitas sosial dengan memisahkan pemahaman "kenyataan dan pengetahuan". Realitas diartikan sebagai kualitas yang terdapat di dalam realitas realitas yang diakui sebagai memiliki keberadaan (being) yang tidak tergantung kepada kehendak kita sendiri. Pengetahuan di definisikan sebagai kepastian bahwa realitas-realitas itu nyata (real) dan memiliki karakteristik yang spesifik.

Teori konstruksi sosial sendiri merujuk pada proses yang terjadi, dimana masyarakat secara bersama-sama membentuk pemahaman mereka tentang dunia. Di dalam kasus ini, pembentukan pemahaman masyarakat ini melalui media sosial yang sedang digandrungi oleh masyarakat. Dalam pembentukan realitas sosial ini akan melalui tiga tahap yaitu, Eksternalisasi atau Objective Reality, Objektivasi atau Simbolic Reality, dan Internalisasi atau Subjective reality. Melalui 3 tahap inilah realitas yang terjadi ini akan dipaparkan sehingga dapat menggambarkan seperti apa konstruksi sosial yang terbentuk melalui media sosial instagram tersebut. Dalam menggunakan teori ini, maka penulis ingin memfokuskan untuk membahas kasus ini melalui teks dan visual terkait 
kemunculan dan respon pengguna di instagram akun@infia_fact tersebut.

\section{PEMBAHASAN}

Dalam pembentukan opini atau proses konstruksi makna yang dibentuk oleh akun instagram @infia fact, dimana terdapat video yang diunggah beserta cuplikan teks atau yang dikenal dengan istilah caption sebagai informasi tambahan guna menguatkan pesan audio visualnya, kemudian pesan tersebut dimaknai oleh para followers akun tersebut hingga mereka merasa tertarik dan menuangkan opini mereka masing-masing.

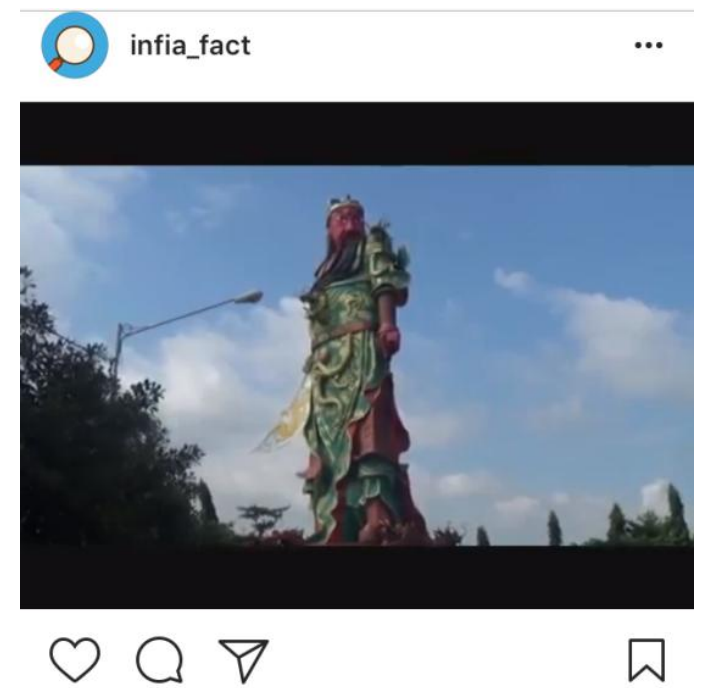

340,325 views
Pemberitaan mengenai patung panglima perang yang diposting oleh akun instagram @infia_fact ini berisikan video berdurasi satu (1) menit yang berusaha menunjukkan kepada khalayak mengenai bentuk fisik patung dilihat dari beberapa sudut pandang melalui beragam pengambilan gambar. Berdasarkan proses eksternalisasi atau objective reality yang ada, akun@infia_fact tampak pada Gambar 2 di bawah ini, mendeskripsikan wujud patung Dewa Kwan Sing Tee Koen yang menjadi viral di Tuban itu melalui sebuah video berdurasi pendek. infia_fact Inilah penampakan patung Kwan Sing Tee Koen atau Patung Dewa Kongco yang berada di Klenteng Kwan Sing Bio, jalan RE Martadinata, Kabupaten Tuban, Jawa Timur.

Kini, patung yang disebut-sebut sebagai patung tertinggi di Asean itu sudah ditutup dengan kain putih setelah menjadi kontroversi di masyarakat dan di dunia maya.

Karena, disebut-sebut patung itu belum mendapatkan izin dari pemerintah setempat. Bahkan, sebagian masyarakat meminta pemerintah setempat untuk merobohkan patung tersebut.

\#infia \#infiafact \#viral \#patung \#patungdewaperang \#klenteng \#klentengkwansingbio \#tuban \#jawatimur

View all 4,060 comments 4 DAYS AGO

Sumber: Instagram di akun@infia_fact

Gambar 2. Dokumentasi Video dan Posting @infia_fact

Video ini disertai dengan adanya caption yang menceritakan mengenai kondisi terkini dari keberadaan patung tersebut. Dalam caption dari postingan @infia_fact ini secara rinci dipaparkan informasi terkait nama patung secara formal hingga penyebutannya, letak atau lokasi patung berdiri, hingga polemik yang sedang terjadi menyangkut berdirinya patung ini. Jika dilihat dari berbagai sudut pandang, nampak jelas ditinjau dari kaidah penulisan jurnalistik berdasarkan informasi yang diberikan cukup akurat, berimbang, tidak memihak salah satu sisi, dan tidak mengundang informasi negatif, sehingga dapat dikatakan bahwa informasi yang disampaikan oleh akun tersebut merupakan informasi yang netral.

Ditinjau secara spesifik berdasarkan penggunaan bahasa, struktur tulisan, serta informasi yang ditayangkan ke dalam caption tersebut, terlihat bahwa akun @infia_fact secara riil memberikan informasi deskriptif bukan interpretatif apalagi investigatif, tanpa ada mengandung kata-kata yang memicu persinggungan Suku, Agama, Ras, dan Antar golongan (SARA) dalam konten berita yang ada. Akun ini hanya menjelaskan polemik yang sedang menyangkut dengan patung tersebut. 
Mengacu pada proses ekternalisasi sebagai usaha pencurahan atau ekspresi diri manusia ke dalam dunia, baik dalam kegiatan mental maupun fisik. Oleh karena itu, media sosial Instagram melaluai akun @infia_fact ini memperlihatkan sifat dasar dari manusia, yang akan selalu mencurahkan diri ke tempat dimana ia berada. Manusia tidak dapat kita mengerti sebagai ketertutupan yang lepas dari dunia luarnya, berusaha menangkap dirinya, dalam proses inilah dihasilkan suatu dunia dengan kata lain sehingga Ia menemukan dirinya sendiri dalam suatu dunia (Bungin, 2008:15). Pada tahap eksternalisasi, tidak terdapat unsur yang menggiring dalam pembentukan opini di khalayak followers. Akun @infia_fact sendiri justru memberitakan dan menginformasikan berdasarkan fakta riil di lapangan tanpa adanya unsur "tambahan" lain yang mewarnai informasi tersebut.

Dalam kepercayaan Konghucu, patung ini merupakan representasi dari Dewa Kongco yang dipercayai oleh para penganutnya sebagai simbol Dewa Keadilan. Patung tersebut dianggap suci dan diagungkan oleh penganut agama Konghucu, dimana letak Dewa Kwan Sing Tee Koen umumnya ditempatkan pada sebelah kiri altar dalam sebuah Klenteng (Moerthiko, 1980:274). Dalam kehidupan bermasyarakat di Indonesia, tentunya karena Indonesia menganut paham demokrasi, yaitu paham dimana masyarakat bebas mengaspirasikan pendapatnya, masyarakat bebas untuk melakukan apa saja selama tidak melanggar hukum, juga masyarakat dilindungi hak dan kebebasannya untuk beribadah sesuai dengan ajaran agama yang dianutnya.

Seperti keseharian yang dilakukan oleh masyarakat penganut agama Konghucu di kota Tuban Provinsi Jawa Timur. Mereka menggunakan haknya untuk melaksanakan ibadah sesuai dengan ajaran agama yang mereka percayai. Pembangunan patung Dewa ini merupakan salah satu bentuk bakti yang mereka curahkan untuk memberi penghormatan pada sang Dewa yang dianggap memiliki kuasa atas hidup mereka. Bila dianalisis berdasar pada proses objektivasi sebagai hasil yang dicapai baik mental maupun fisik dari kegiatan eksternalisasi manusia, dimana benda maupun bahasa sebagai perwujudan eksternalisasi tersebut menjadi realitas yang objektif. Sejalan dengan itu, tata cara peribadatan Khonghucu merupakan bentuk eksternalisasi yang dijalankan para pemeluknya sebagai penghasil dari produk kebudayaan. Hal ini dapat dipersepsikan demikian, karena kebudayaan dianggap sebagai realitas objektif berbeda dengan kenyataan subyektif perorangan (Bungin, 2008:15).

Ditinjau dari perspektif hukum, memang patung ini belum memperoleh perijinan dari pemerintah setempat sehingga wajar jika banyak masyarakat yang menyebutkan bahwa patung tersebut tidak layak untuk dibangun. Kondisi ironis ini sebenarnya berakar dari pola kebijakan pemerintah Orde Baru yang tidak mengakui agama Khonghucu, hanya organisasi keagamaan dan rumah abu yang diperbolehkan untuk terus beroperasi. Selama umat Khonghucu tunduk di bawah aturan pemerintah yang bersifat persekusi atau penindasan, mereka masih diberi kesempatan untuk berkumpul dalam dua organisasi. Pertama, perkumpulan Sam Kauw Hwee yang berikutnya atas dasar kebijakan pemerintah yang melarang penggunaan nama Tionghoa, maka berubah menjadi "Gabungan Tridharma Indonesia (GTI)", dimana Tridharma yang dimaksud antara lain: Budhisme, Taoisme, dan Konfusianisme. Kedua, organisasi yang didirikan sejak tanggal 11-12 Desember 1954 bernama Majelis Tinggi Agama Khonghucu Indonesia (MATAKIN) dengan organisasi-organisasi yang bernaung dibawahnya yaitu: MATAKIN di berbagai Propinsi, Majelis Agama Khonghucu Indonesia (MAKIN) kota-kota di Tanah Air, serta Kebaktian Agama Khonghucu Indonesia (KAKIN). Perkembangan selanjutnya dua organisasi ini tetap berusaha dipertahankan oleh pemerintahan era Orde Baru, agar lebih teratur dan sesuai dengan penghayatan keagamaan dan kepercayaan tertentu atau justru dalam rangka meningkatkannya dalam segala aspek kehidupan umat manusia. 
Khong Kauw Hwee atau Perkumpulan Konfusian di beberapa kota kemudian mendirikan Perserikatan Kong Jiao Hui Indonesia sebagai wadah yang mempertemukan mereka sejak 16 April 1955. Selain itu, terdapat pula perkumpulan keagamaan lain yang disebut Sam Kauw Hwee atau Perkumpulan Tiga Agama, selanjutnya dikenal dengan sebutan Tridharma, yang didirikan oleh penulis kenamaan Kwee Tek Hoay (1886-1951) dan ditujukan untuk memajukan Konfusianisme, Taoisme, dan Buddhisme. Pada tahun 1984, pemerintah membentuk Wali Umat Budha (Walubi) yang diharapkan mampu merubah keberadaan klenteng sebagai tempat ibadat etnis Tionghoa menjadi vihara. Jika klenteng tidak berubah menjadi vihara, maka mereka tidak boleh menjalankan aktivitasnya (Tan, 2014:2-31).

Melihat intensitas represi pemerintah hingga ke ranah agama dan kepercayaan etnis Tionghoa, tidaklah mengherankan ketika Presiden Soeharto dinyatakan lengser dari jabatan sebagai presiden, organisasi yang pertama menyatakan kebangkitannya kembali adalah Majelis Tinggi Agama Khonghucu Indonesia (MATAKIN). Organisasi keagamaan yang telah berdiri sejak 1967 ini segera mengadakan kongres pada tahun 1998. Di masa pemerintahan Presiden Abdurrachman Wahid yang singkat, mampu mengakhiri kisah kelam warga Tionghoa yang menganut agama Khonghucu selama lebih dari tiga dasawarsa. Terobosan yang ditempuh adalah mencabut Instruksi Presiden Nomor 14 Tahun 1967 yang melarang segala aktivitas berbau Tionghoa dan Surat Edaran (SE) Menteri Dalam Negeri Nomor 477/74054/BA.01.2/4683/95. Kondisi ini sebenarnya telah mengembalikan keadaan seperti pada masa Orde Lama, yang diatur melalui Undang-Undang (UU) Nomor 5 Tahun 1969 dan mengakui ada enam agama di Indonesia, yaitu: Islam, Kristen Protestan, Kristen Katolik, Hindu, Buddha, dan Khonghucu. Isi UU ini sama persis dengan Penetapan Presiden Nomor 1 Tahun 1965 yang mengakui enam agama. Kedua peraturan ini semakin dikuatkan oleh UU
Nomor 1 Tahun 1974 tentang Perkawinan, yang mensyaratkan perkawinan sah apabila dilakukan menurut hukum masing-masing agama dan kepercayaan itu. ${ }^{1}$

Tinjauan dari perspektif sejarah juga diperoleh bahwa tokoh yang dijadikan patung ini, yaitu Dewa Kwan Sing Tee Koen tidak memiliki korelasi bahkan kontribusi apapun bagi negara Indonesia. Banyak Masyarakat yang mempertanyakan alasan di balik pembangunan patung yang diinformasikan sebagai patung yang tertinggi di kawasan Asia Tenggara. Di sisi lain, pendirian patung tersebut berada di wilayah Negara Kesatuan Republik Indonesia, sementara banyak pahlawan Indonesia yang dianggap jauh lebih layak untuk dibangunkan patungnya. Di sisi lain, jika dilihat dari sisi hak dan kebebasan berpendapat serta kebebasan beribadah, tentunya reaksi dari masyarakat yang menolak untuk berdirinya patung ini, bahkan tidak sedikit di antara mereka meminta agar patung tersebut segera dirobohkan karena patung ini melanggar kebebasan beribadah bagi setiap masyarakat.

Dari tiga tahap yang harus dilewati agar sebuah realitas itu terbentuk, internalisasi atau disebut juga subjective reality adalah tahap yang ketiga. Tahap ini merupakan tahap dimana pembentukan opini sudah terjadi di masyarakat, lebih tepatnya

\footnotetext{
1 Di Era Orde Baru muncul suatu keputusan pemerintah yang tertuang melalui Surat Edaran (SE) Menteri Dalam Negeri No. 477/74054/BA.01.2/4683/95, tanggal 18 November 1978, yang menyatakan hanya ada lima agama di Indonesia, yaitu: Islam, Kristen Protestan, Kristen Katolik, Hindu, dan Buddha. Ironisnya lagi, 12 tahun kemudian pemerintah melalui Mendagri kembali menerbitkan surat serupa bernomor 77/2535/POUD, tanggal 25 Juli 1990. Ditambah lagi pada 28 November 1995, keluar instruksi serupa melalui Surat Kepala Kantor Wilayah Departemen Agama Provinsi Jawa Timur No. $683 / 95$.
} 
komentar-komentar dari netizen yang memfollow akun instagram @infia_fact.

Akun@infia_fact memiliki sekitar 2,9 juta followers. Para pengikut akun tersebut mempunyai kebutuhan tersendiri, yaitu mendapatkan informasi dan para followers juga diperbolehkan untuk memberikan opini baik itu opini negatif atau pun positif. Berita patung di Kota Tuban ini mengajak para followers atau netizen beramai-ramai menanggapi berita tersebut dengan memberikan tanggapan opini negatif maupun positif, baik yang ditujukan untuk membela atau justru sebaliknya menjatuhkan.

Pendapat pada followers @infia fact terhadap berita patung di Tuban juga sangat beraneka ragam dikarenakan pandangan setiap orang berbeda-beda perspektifnya. Ada salah satu followers yang memang ingin bersikukuh pada opini bahwa berdirinya patung tersebut merupakan hal yang salah. Di sisi lain, ada pula yang tetap membela bahwa patung tersebut tidak ada salahnya jika dibangun.

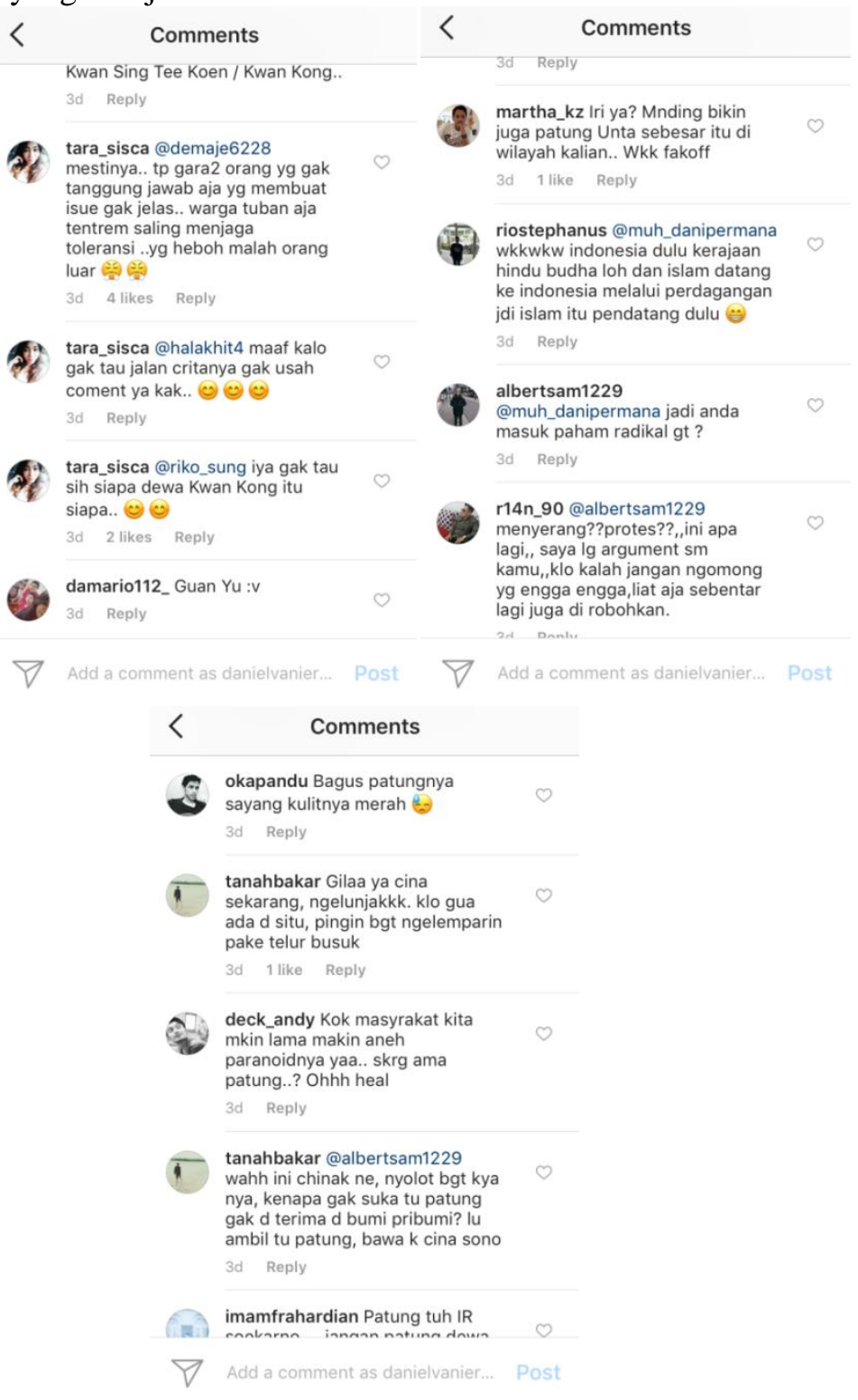

Sumber: Instagram di akun @infia_fact

Gambar 3. Dokumentasi komentar netizen di akun @infia_fact 
Terdapat banyak akun yang memberikan komentar-komentar miring dengan tendensi sikap menjatuhkan dan sebenarnya sangat tidak pantas untuk disampaikan di media sosial hingga dapat disimak oleh pengguna internet di seluruh dunia dapat mengaksesnya. Adapun netizen yang membentuk dan menggiring opininya sendiri untuk merusak kerukunan dan persatuan bangsa Indonesia, seperti komentar yang dilontarkan oleh akun @tanahbakar pada Gambar 3, isi dari komentar tersebut sangat menyudutkan salah satu etnis maupun asal budayanya di Indonesia. Dengan komentarkomentar yang bernada rasis tersebut, banyak netizen lain yang menjawab komentardari akun@tanahbakar kemudian terjadilah perdebatan hingga memicu gelombang demonstrasi yang ditunjukkan pada Gambar 4.

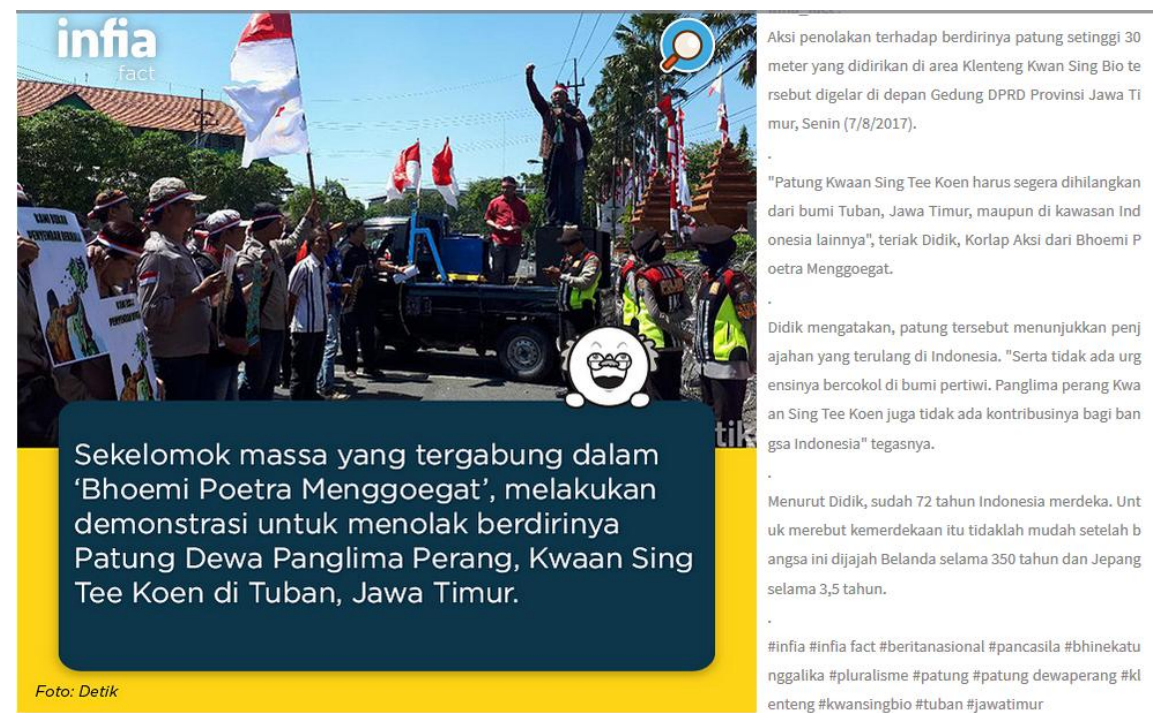

Sumber: www.pintagram.com/u/infia_fact/

\section{Gambar 4. Dokumentasi Berita Demonstrasi di akun @infia_fact}

Bentuk internalisasi yang dipahami secara subyektif oleh masing-masing individu berdialektika dengan pendapat yang bersifat anomali, nampak dari komentar-komentar yang muncul tidak hanya negatif melainkan juga mendukung berdirinya patung tersebut. Banyak netizen yang mendukung dan memberikan tanggapan positif dengan memberi saran agar mempertahankan keberadaan patung tersebut. Tak sedikit pula yang berpendapat bahwa patung tersebut dapat berguna sebagai objek wisata di Kota Tuban.

Ketika wujud internalisasi secara subyektif kemudian disuarakan secara masif dalam lingkup kelompok hingga ke khalayak massa, maka fenomena ini dapat dipahami sebagai proses eksternalisasi yang berlaku secara obyektif. Awalnya kasus ini menyeruak ke permukaan diakibatkan oleh surat ijin yang belum dikeluarkan oleh pemerintah, namun justru merambat hingga ke permasalahan yang menyinggung unsur SARA. Pada gilirannya, biduk pendapat terbagi dalam dua (2) alur. Kanal positif akan cenderung membendung persepsi negatif, namun perspektif ini tidak selamanya berlaku di ranah online. Faktanya gerakan akar rumput muncul dalam bentuk gelombang demonstrasi yang menyebut diri mereka sebagai Kelompok "Bhoemi Poetra Menggoegat". Hal ini berpotensi dapat mengancam kerukunan hidup berbangsa dan bertanah air Indonesia, diakibatkan timbulnya saling membenci satu dengan yang lain meski harapan bersama adalah hidup dengan damai saling berdampingan. 


\section{SIMPULAN}

Dari uraian pembahasan yang telah dipaparkan sebelumnya, maka dapat ditarik kesimpulan bahwa media sosial itu memiliki pengaruh kuat di kalangan masyarakat khususnya pengguna media instagram, dimana instagram merupakan salah satu platform yang sangat diminati oleh masyarakat modern dewasa ini. Penggunaan akun instagram berpotensi membangun opini-opini di masyarakat secara efektif, ketika terdapat sebuah persoalan yang menarik di akun instagram, maka serempak akan banyak sekali netizen yang akan menanggapi baik dengan komentar positif maupun negatif.

Walaupun pemberitaan mengenai Patung Jendral di Tuban tersebut diinformasikan tanpa adanya tendensi apapun, namun opini-opini yang terbentuk di kalangan netizen ini tidak terkendali bahkan berkembang ke ranah offline dalam wujud demonstrasi. Konstruksi realitas pada informasi semakin terpetakan dengan sangat jelas alurnya. Sekalipun akan ditanggapi berbeda-beda oleh setiap netizen dan sebagian berusaha meredam secara positif melalui komentar yang ada, namun perlu adanya langkah strategis agar konstruksi sosial terhadap realitas melalui media ini tidak membawa dampak yang lebih kompleks dalam kehidupan nyata antar umat manusia Indonesia dalam bingkai Bhinneka Tunggal Ika.

\section{DAFTAR PUSTAKA}

Alex Sobur. 2009. Analisis Teks Media "Suatu Pengantar untuk Analisis Wacana, Analisis Semiotika, dan Analisis Framing. PT. Remaja Rosdakarya, Bandung.

Bungin, Burhan. 2008. Sosiologi Komunikasi (Teori, Paradigma, dan Discourse Teknologi Komunikasi di Masyarakat). Kencana Prenada Media Group, Jakarta.

Hidayah, Zulyani. 2015. Ensiklopedi Suku Bangsa di Indonesia. Yayasan Pustaka Obor Indonesia, Jakarta.

Moerthiko. 1980. Riwayat Klenteng, Vihara, Lithang, Tempat Ibadat Tridharma seJawa. Empeh Wong Kam Fu, Semarang.

Poloma, Margareth. 2004. Sosiologi Kontemporer. PT. Raja Grafindo Persada, Jakarta.

Tan, Chee-Beng. 2014. After Migration and Religious Affiliation: Religions, Chinese Identities, and Transnational Network. World Scientific, Singapore.

https://www.pintaram.com/u/infia_fact/1575 394211062964513_1302384083 diakses pada tanggal 09 September 2017 pk.17.09 WIB 